\title{
Enantioselective $\alpha$-Hydroxylation of 2-Arylacetic Acid Derivatives and Buspirone Catalyzed by Engineered Cytochrome P450 BM-3
}

\author{
Marco Landwehra ${ }^{\mathrm{a}}$ Lisa Hochrein ${ }^{\mathrm{a}}$, Christopher R. Otey $^{\mathrm{a}}$, Alex Kasrayan ${ }^{\mathrm{b}}$, Jan-E. \\ Bäckvall ${ }^{\mathrm{b}}$, and Frances H. Arnolda \\ a Division of Chemistry and Chemical Engineering 210-41, California Institute of Technology, Pasadena, \\ CA 91125-4100, USA \\ b Department of Organic Chemistry, Arrhenius Laboratory, Stockholm University, SE-106 91 Stockholm, \\ Sweden
}

\section{Abstract}

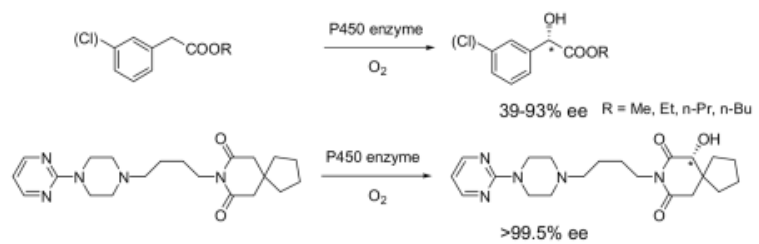

Here we report that an engineered microbial cytochrome P450 BM-3 (CYP102A1 subfamily) efficiently catalyzes the $\alpha$-hydroxylation of phenylacetic acid esters. This P450 BM-3 variant also produces the authentic human metabolite of buspirone, R-6-hydroxybuspirone, with $99.5 \%$ ee.

Biocatalytic processes are becoming increasingly important in organic synthesis ${ }^{1}$ due to their unique selectivity advantages over conventional methods. ${ }^{2,3}$ Common biocatalytic transformations include enantioselective transesterification, ${ }^{4}$ reduction of ketones, ${ }^{2}$ BaeyerVilliger oxidation 5 and epoxide opening. ${ }^{6}$ Recently, biocatalytic hydroxylations have attracted considerable interest. 7,8 Here we report a variant of cytochrome P450 BM-3 (BM-3; isolated from Bacillus megaterium) capable of efficient and highly enantioselective hydroxylation at the alpha position of certain carboxylic and peptide groups.

BM-3 is a well-studied, NADPH-dependent monooxygenase that hydroxylates long-chain fatty acids at the $\omega-1, \omega-2$, and $\omega-3$ positions at high rates. ${ }^{9}$ BM- 3 has provided an evolvable protein framework for obtaining modified or new activities. Rational design and directed evolution approaches have created BM-3 variants with activity on medium-chain fatty acids, 10 high selectivity for 2-hydroxylation of n-alkanes such as hexane, ${ }^{11}$ activity on aromatic compounds 12 and the ability to oxidize ethane to ethanol. ${ }^{13} \mathrm{BM}-3$ variants were also recently shown to yield human drug metabolites. ${ }^{14}$

2-Aryl-2-hydroxyacetic acid derivatives are pharmaceutical building blocks for semi-synthetic penicillins, cephalosporin and antiobesity agents. ${ }^{15}$ Mandelic acid derivatives have been found to act as thrombin inhibitors and anticoagulants. ${ }^{16}$ Due to the high level of interest in these compounds, a number of methods have been developed for their synthesis in enantiomerically pure form. 17 These methods often use racemic substrates or intermediates for resolution or selective hydrolysis rather than direct enantioselective hydroxylation at the targeted position. 
No cytochrome $\mathrm{P} 450$ that accepts 2-arylacetic acids as substrate is reported in the literature. $\alpha$-Hydroxylation of carboxylic acids has only been reported for P450 BS $\beta$ and SP $\alpha$, both of which are active only on long-chain fatty acids (e.g. myristic acid) and only as peroxygenases. 18 We were therefore interested in whether BM-3 variants could hydroxylate small aromatic carboxylic acids.

Observations in our laboratory suggested that small charged molecules such as carboxylic acids are unlikely to be accepted by the hydrophobic active site of BM-3. Recent studies have shown that protecting groups can strongly influence $\mathrm{P} 450$ activity. 8,19 Therefore, using differentsized ester groups to mask the acid we investigated whether the chain length of the substrate influences binding and specificity of hydroxylation.

BM-3 shows low activity with moderate enantioselectivity on 2-phenylacetic acid esters (Table 1). For example, the methyl and propyl esters of $(S)$-mandelic acid were obtained in 90 and $82 \%$ enantiomeric excess (ee), respectively. The low total turnover number (TTN; mol product per mol catalyst) for BM-3 likely reflects an active site evolved for the alkyl tails of fatty acids, which leads to increased uncoupling (consuming NADPH co-factor without oxidizing the substrate) for non-natural substrates.

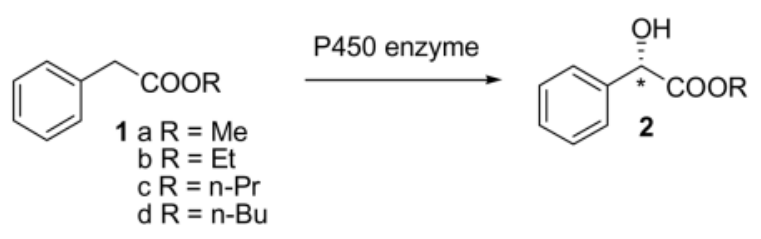

It is known that mutations at F87 can increase BM-3 activity towards small aromatic compounds. ${ }^{20}$ We found that the F87A mutation increased the TTN nearly 10 -fold and increased regioselectivity for the $\alpha$-hydroxylated product to as high as $99 \%$ on the propyl ester. The ee for this reaction depends on the size of the ester group and varies from 43 to $85 \%$ ee, with the highest value for the propyl ester. We also tested variants of BM-3 which were evolved previously for high activity on medium-chain alkanes, 9-10A and 1-12G (differing by 14 and 16 mutations, respectively, from the wildtype sequence), ${ }^{11}$ to see if they exhibit higher TTN on substrates 1a-d. Bioconversions with 1-12G showed 5-20 fold less conversion and very low regioselectivity for the desired products in comparison to BM-3-F87A and was therefore excluded from further investigations (data not shown). Variant 9-10A, on the other hand, showed increased TTN on the propyl and butyl esters. We then constructed 9-10A with the F87A mutation and found that this 9-10A-F87A variant has the highest TTN (up to 1640) and gives propyl mandelate in $93 \%$ ee. Each 9-10A-F87A enzyme catalyzes the hydroxylation of $254 \pm 29$ molecules per minute with $25 \%$ coupling to cofactor consumption.

9-10A-F87A also hydroxylates substituted substrates such as $m$-chloro phenylacetic acid (Table 2). The ee values are comparable to those obtained for phenylacetic acid, although the highest ee was obtained for the butyl rather than the propyl ester.<smiles>[R]OC(=O)Cc1cccc(Cl)c1</smiles>

$$
\begin{aligned}
3 \mathrm{~b} R & =\mathrm{Et} \\
\mathrm{c} R & =\mathrm{n}-\mathrm{Pr} \\
\mathrm{d} R & =\mathrm{n}-\mathrm{Bu}
\end{aligned}
$$

The reaction can be improved with a system which regenerates the expensive NADPH cofactor in situ. ${ }^{21}$ Use of a regeneration system involving isocitrate dehydrogenase and isocitrate increased the TTN for the production of propyl mandelate by 9-10A-F87A from 1640 to over 5800 in a $3 \mathrm{~h}$ reaction with NADPH concentration maintained at $50 \mu \mathrm{M}$. Lower concentrations increased TTN; high concentrations of cofactor inhibit the wildtype enzyme 22 and possibly 
our variants. The ee and selectivity were unchanged. Using the regeneration system with 500 $\mathrm{nM}$ enzyme yielded $96 \%$ conversion of $15 \mathrm{ml}$ of $1 \mathrm{mM}$ propyl phenylacetate in a batch reaction after $7 \mathrm{~h}$.

Motivated by the high enantioselectivity and activity of this variant, we decided to test its ability to hydroxylate the $\alpha$-position of the peptide group of buspirone (Buspar®, 4). Buspirone is a known substrate of human CYP3A4, ${ }^{3}$ and both it and its human metabolite, 6hydroxybuspirone (5), are anti-anxiety agents. ${ }^{24}$ Bioconversion on $0.5 \mathrm{ml}$ scale with $50 \mathrm{nM}$ 9-10A-F87A gave 3800 TTN and $8.9 \%$ conversion of a $2 \mathrm{mM}$ buspirone solution. $(R)-6$ hydroxybuspirone (5) was the sole product and was obtained with $>99.5 \%$ ee. Interestingly, this $R$-enantioselectivity is the opposite of that usually observed when buspirone is converted by natural microbial cultures. ${ }^{24} \mathrm{~A} 7 \mathrm{~h}$ bioconversion with cofactor regeneration yielded up to $72 \%$ conversion. Thus the bacterial P450 variant efficiently produces an authentic human metabolite of the drug.

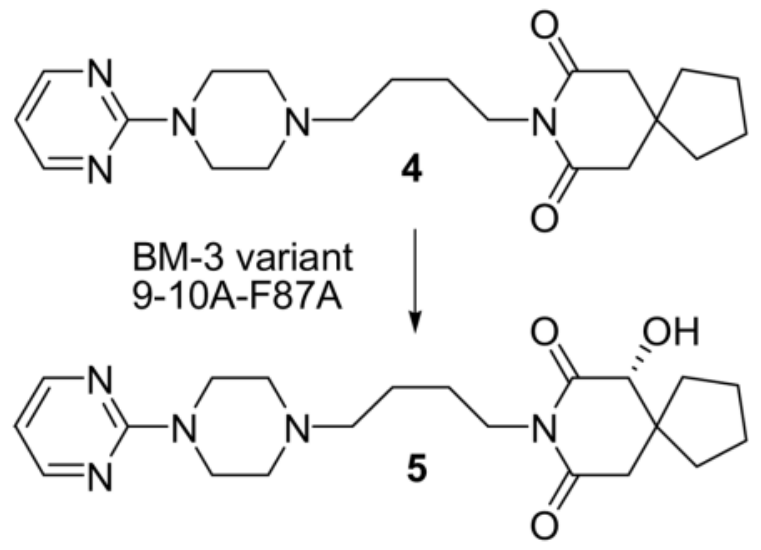

The F87A mutation likely carves out space in the BM-3 active site and allows a wider range of substrates to be bound with a defined orientation. By varying the chain length of the ester substrates we can improve catalyst selectivity and probe the active site. Enantioselective hydroxylation in the $\alpha$-position of carboxylic acid or peptide derivatives represents a novel reaction type by $\mathrm{P} 450 \mathrm{BM}-3$ and opens up a new biocatalytic route to $(S)$-mandelic acid derivatives and $(R)$-6-hydroxybuspirone.

\section{Supplementary Material}

Refer to Web version on PubMed Central for supplementary material.

\section{Acknowledgements}

Financial support from the National Science Foundation (BES9981770), NIH Grant R01 GM068664-01, NSF Graduate Research Fellowship program (LH) and the Swedish Foundation for Strategic research (AK and JEB) is gratefully acknowledged. Special thanks to N Dalleska and M Chen for assistance with the GC, P Meinhold for cloning the 910A-F87A variant, R Patel, S Kiang, and J. Depue (Bristol-Myers Squibb) for assistance with the buspirone analytics.

\section{References}

1. de Meijere, A.; Diederich, F. Metal-catalyzed Cross-Coupling Reactions. Wiley-VCH; Weinheim: 2004.

2. Bornscheuer, UT.; Kaslauskas, RJ. Hydrolases in Organic Synthesis. Wiley-VCH; Weinheim: 1999. 
3. Faber, K. Biotransformations in Organic Chemistry. 4. Springer; Berlin: 2000. Drauz, K.; Waldmann, H.; Roberts, SM. Enzyme Catalysis in Organic Synthesis. Wiley-VCH; Weinheim: 2002. (c) Koeller KM, Wong CH. Nature 2001;409:232-40. [PubMed: 11196651]

4. (a) Hummel W. Adv Biochem Eng Biotechnol 1997;58:145-84. [PubMed: 9103913] (b) MartinMatute B, Edin M, Bogar K, Kaynak FB, Backvall JE. J Am Chem Soc 2005;127:8817-8825. [PubMed: 15954789] (c) Pamies O, Bäckvall JE. Curr Opin Biotechnol 2003;14:407-413. [PubMed: 12943850]

5. (a) Reetz MT, Brunner B, Schneider T, Schulz F, Clouthier CM, Kayser MM. Angew Chem Int Ed Engl 2004;43:4075-4078. [PubMed: 15300699] (b) Alphand V, Carrea G, Wohlgemuth R, Furstoss R, Woodley JM. Trends Biotechnol 2003;21:318-23. [PubMed: 12837617]

6. Kroutil W, Mischitz M, Faber K. J Chem Soc Perkin Trans 1997;1:3629-3636.

7. (a) Cirino PC, Arnold FH. Angew Chem Int Ed Engl 2003;42:3299-301. [PubMed: 12876749] (b) Meunier B, de Visser SP, Shaik S. Chem Rev 2004;104:3947-80. [PubMed: 15352783]

8. (a) Munzer DF, Meinhold P, Peters MW, Feichtenhofer S, Griengl H, Arnold FH, Glieder A, de Raadt A. Chem Comm 2005:2597-9. [PubMed: 15900339] (b) Li Z, Chang D. Curr Org Chem 2004;8:164758.

9. (a) Narhi LO, Fulco AJ. J Biol Chem 1986;261:7160-9. [PubMed: 3086309] (b) Schwaneberg U, Schmidt-Dannert C, Schmitt J, Schmid RD. Anal Biochem 1999;269:359-366. [PubMed: 10222011]

10. Li QS, Schwaneberg U, Fischer M, Schmitt J, Pleiss J, Lutz-Wahl S, Schmid RD. Biochim Biophys Acta 2001;1545:114-121. [PubMed: 11342037]

11. Peters MW, Meinhold P, Glieder A, Arnold FH. J Am Chem Soc 2003;125:13442-13450. [PubMed: 14583039]

12. (a) Appel D, Lutz-Wahl S, Fischer P, Schwaneberg U, Schmid RD. Journal of Biotechnology 2001;88:167-171. [PubMed: 11403851] (b) Li QS, Schwaneberg U, Fischer P, Schmid RD. Chem Eur J 2000;6

13. Meinhold P, Peters MW, Chen MM, Takahashi K, Arnold FH. Chem Bio Chem 2005;6:1765-1768.

14. Otey CR, Bandara B, Lalonde J, Takahashi K, Arnold FH. Biotechnol Bioeng 2006;93:494-499. [PubMed: 16224788]

15. (a) Saravanan P, Singh VK. Tetrahedron Lett 1998;39:167-170. (b) Furlemmeier, A.; Quitt, P.; Vogler, K.; Lanz, P. US Patent. 3, 957, 758. 1976. (c) Mill, J.; Schmiegel, KK.; Sha, WN. US Patent. 4, 391, 826. 1983. Coppola, GM.; Schuster, HF. alpha-Hydroxy Acids in Enantio-selective Syntheses. Wiley-VCH; Weinheim: 1997.

16. (a) Inghardt, T.; Johansson, A.; Svensson, A. PCT Int Appl. WO 2002044145. 2002. (b) Inghardt, T.; Nystöm, JE. PCX Int Appl. WO 2000042059. 2000.

17. (a) Campbell RF, Fitzpatrick K, Inghardt T, Karlsson O, Nilsson K, Reilly JE, Yet L. Tetrahedron Lett 2003;44:5477-5481. (b) Yamamoto K, Oishi K, Fujimatsu I, Komatsu KI. Appl Environ Microbiol 1991;57:3028-3032. [PubMed: 1660699] (c) Huang HR, Xu JH, Xu Y, Pan J, Liu X. Tetrahedron-Asymmetr 2005;16:2113-2117. (d) DeSantis G, et al. J Am Chem Soc 2002;124:90245. [PubMed: 12148986] (e) Huerta FF, Laxmi YR, Backvall JE. Org Lett 2000;2:1037-40. [PubMed: 10804548] (f) Wang PY, Tsai SW. Enzyme Microb Technol 2005;37:266-71.

18. (a) Lee DS, Yamada A, Sugimoto H, Matsunaga L, Ogura H, Ichihara K, Adachi S, Park SY, Shiro Y. J Biol Chem 2003;278:9761-9767. [PubMed: 12519760] (b) Matsunaga I, Sumimoto T, Ueda A, Kusunose E, Ichihara K. Lipids 2000;35:365-371. [PubMed: 10858020]

19. Lussenburg BM, Babel LC, Vermeulen NP, Commandeur JN. Anal Biochem 2005;341:148-155. [PubMed: 15866539]

20. Sulistyaningdyah WT, Ogawa J, Li QS, Maeda C, Yano Y, Schmid RD, Shimizu S. Appl Microbiol Biotechnol 2005;67:556-62. [PubMed: 15549292]

21. Schwaneberg U, Otey C, Cirino PC, Farinas E, Arnold FH. J Biomol Screen 2001;6:111-7. [PubMed: 11689105]

22. Murataliev MB, Feyereisen R. Biochemistry 2000;39:12699-707. [PubMed: 11027150]

23. Zhu M, Zhao W, Jimenez H, Zhang D, Yeola S, Dai R, Vachharajani N, Mitroka J. Drug Metab Dispos 2005;33:500-7. [PubMed: 15640381]

24. Hanson RL, Parker WL, Brzozowski DB, Tully TP, Liu M, Kotnois A, Patel RN. Tetrahedron: Asymmetry 2005;16:2711-2716. 
Table 1

Chiral Product Analysis of P450 Monooxygenase Catalyzed Hydroxylation of the Indicated Phenylacetic Acid Esters

\begin{tabular}{|c|c|c|c|c|}
\hline Enzyme & Substrate & TTN & $\%$ Selectivity ${ }^{a}$ & $\%$ ee $(S)$ \\
\hline \multirow{4}{*}{ BM-3 } & 1a (Me) & 105 & 44 & 90 \\
\hline & $1 \mathrm{~b}(\mathrm{Et})$ & 92 & 29 & 70 \\
\hline & 1c (Pr) & 63 & 17 & 82 \\
\hline & $1 d(\mathrm{Bu})$ & 20 & 6 & 71 \\
\hline \multirow[t]{4}{*}{ BM-3-F87A } & $1 \mathrm{a}(\mathrm{Me})$ & 25 & 25 & 43 \\
\hline & $1 \mathrm{~b}(\mathrm{Et})$ & 234 & 86 & 74 \\
\hline & $1 \mathrm{c}(\operatorname{Pr})$ & 623 & 99 & 85 \\
\hline & $1 \mathrm{~d}(\mathrm{Bu})$ & 396 & 88 & 75 \\
\hline \multirow[t]{4}{*}{$9-10 \mathrm{~A}$} & 1a (Me) & 102 & 57 & 77 \\
\hline & $1 \mathrm{~b}(\mathrm{Et})$ & 63 & 63 & 52 \\
\hline & $1 \mathrm{c}(\operatorname{Pr})$ & 77 & 41 & 85 \\
\hline & $1 d(\mathrm{Bu})$ & 86 & 25 & 95 \\
\hline \multirow{4}{*}{ 9-10A-F87A } & 1a (Me) & 27 & 12 & 39 \\
\hline & $1 \mathrm{~b}(\mathrm{Et})$ & 115 & 75 & 56 \\
\hline & $1 \mathrm{c}(\mathrm{Pr})$ & 1640 & 88 & 93 \\
\hline & $1 \mathrm{~d}(\mathrm{Bu})$ & 660 & 76 & 89 \\
\hline
\end{tabular}

${ }^{a}$ Regioselectivity for mandelic acid esters, side products due to hydroxylation or hydrolysis of ester chain. 
Table 2

Chiral Product Analysis of P450 Monooxygenase Catalyzed Hydroxylation of Chlorinated Phenylacetic Acid Esters

\begin{tabular}{ccccc}
\hline Enzyme & Substrate & TTN & \% Selectivity & \% ee \\
\hline 9-10A-F87A & 3b (Et) & 180 & 70 & 57 \\
& 3c (Pr) & 940 & 90 & 89 \\
& 3d (Bu) & 700 & 89 & 94 \\
\hline
\end{tabular}

${ }^{a}$ Regioselectivity for mandelic acid ester derivatives 